\title{
Plasma Lipids as Biomarkers for Alzheimer's Disease: A Systematic Review
}

\author{
Mehak Agarwal $^{1}$, Safeera Khan ${ }^{1}$ \\ 1. Internal Medicine, California Institute of Behavioral Neurosciences \& Psychology, Fairfield, USA
}

Corresponding author: Mehak Agarwal, mehakagarwal96@gmail.com

\begin{abstract}
Alzheimer's disease (AD) is caused by several risk factors leading to dementia. It's diagnosis usually depends on clinical presentation and certain biomarkers in the cerebrospinal fluid (CSF). The brain has a high content of cholesterol and the metabolism of cholesterol in the brain can be associated with beta-amyloid plaques formation, which is seen in Alzheimer's disease. Given these implications, we studied if plasma lipid levels can vary in Alzheimer's disease and if these can be used as biomarkers to diagnose and predict the progression of Alzheimer's disease. Certain mutations in the brain cholesterol transport receptors and proteins and their association with Alzheimer's were also studied. This systematic review abides by the Preferred Reporting Items for Systematic Reviews and Meta-Analyses (PRISMA) guidelines. We searched multiple databases, such as Pubmed, Google Scholar, Pubmed central, ScienceDirect, Web of Science, and Medline with the help of keywords like Alzheimer's disease, cognitive impairment, plasma lipid biomarkers, cholesterol, brain cholesterol metabolism separately and in combination with each other. We collected 49 quality appraised articles on the association between plasma lipids and Alzheimer's disease and the genetic mutations in alleles related to cholesterol metabolism and Alzheimer's disease by applying the inclusion and exclusion criteria. Based on the finding of the studies reviewed, we found an association between plasma lipids, polymorphisms in genes associated with cholesterol transport, and Alzheimer's disease. Increased serum low-density lipoprotein (LDL-C), triglycerides (TG), total cholesterol (TC), sphingolipids, 24S hydroxycholesterol (24S-HC), $27 \mathrm{O}$ hydroxycholesterol (27O-HC) was associated with Alzheimer's. Decreased high-density lipoprotein (HDL-C) and phospholipids were noticed. Genetic mutations in apolipoprotein E (ApoE), apolipoprotein B (ApoB), apolipoprotein A (ApoA), ATP binding cassette transporter 1 (ABCA1), ATP binding cassette transporter 7 (ABCA7), amyloid precursor protein (APP), cytochrome P450 family 46 subfamilies A member 1 (CYP46A1), presenilin 1 (PSEN1), presenilin 2 (PSEN2) are also associated with increased risk of Alzheimer's disease. This study found an association between plasma lipids and Alzheimer's, proving that plasma lipids can be used as biomarkers for early diagnosis of Alzheimer's disease. It may also help predict the prognosis and stage the disease severity. Further studies are needed to find out the exact mechanism behind these changes.
\end{abstract}

Received 10/23/2020

Review began 11/09/2020

Review ended 12/09/2020

Published 12/10/2020

() Copyright 2020

Agarwal et al. This is an open access article distributed under the terms of the Creative Commons Attribution License CC-BY 4.0., which permits unrestricted use, distribution, and reproduction in any medium, provided the original author and source are credited.
Categories: Internal Medicine, Neurology, Psychiatry

Keywords: alzheimers disease, cognitive impairment, plasma lipid biomarkers, cholesterol, brain cholesterol metabolism

\section{Introduction And Background}

Alzheimer's disease and other causes of dementia constitute an increasing challenge in the health care system worldwide. There are approximately 50 million people currently living with dementia [1]. Alzheimer's disease is associated with a high mortality rate; it is the seventh leading cause of death in older people [2]. Alzheimer's disease (AD) was discovered based on the findings of an autopsy, which suggested atrophy of the brain cortex [3].

Alzheimer's disease is characterized by memory loss and cognitive impairment due to degeneration in the brain. It's the most common type of dementia. It's a progressive disease beginning with mild cognitive impairment resulting in memory loss, language, and thinking ability. Mild cognitive impairment is the phase between the cognitive impairment normally seen in the elderly and the cognitive decline due to complex conditions causing dementia. Pathologically, Alzheimer's disease is due to the building up of beta amyloid-forming plaques in the brain cortex and deposition of phosphorylated tau protein in the neurofibrillary tangles [3].

Both genetic and non-genetic risk factors can cause Alzheimer's disease. Ageing is the most important risk factor. Other causes include cerebrovascular disease, increased blood pressure, increase insulin resistance in type two diabetes mellitus, bodyweight, metabolic syndrome, smoking, traumatic brain injury, plasma lipid levels, diet, intellectual activity, and decreased physical activity [4]. Research focusing on the genetic component of Alzheimer's disease shows that Individuals with the apolipoprotein E4 (ApoE4) allele are at a higher chance of the disease [5-7]. Early-onset Alzheimer's disease is usually caused due to genetic variants in genes coding for amyloid precursor protein (APP) or presenilin (PSEN 1 and PSEN 2) [8-10]. Late-onset Alzheimer's is not known to be due to mutations in these genes. 
Currently, the diagnosis of Alzheimer's disease is made based on the clinical presentation of the patients and the laboratory diagnosis of three biomarkers in the cerebrospinal fluid (CSF): amyloid-beta 42, total tau, and phospho-tau, out of which beta-amyloid 42 is the most sensitive biomarker [11]. Biomarkers of cognitive decline help to detect the biochemical and pathological changes of $\mathrm{AD}$ in the cerebrospinal fluid.

Cerebrospinal fluid is present in the brain, and hence a sample of the cerebrospinal fluid would help us evaluate the onset and progression of the disease. But a collection of a cerebrospinal fluid sample is an inconvenient process requiring a lumbar puncture, which is not routinely done in primary care, geriatric care, or psychiatry. This has led to the discovery of other biomarker molecules found in the plasma, which can help us evaluate Alzheimer's disease without the need for invasive, expensive tests and can also be done as large-scale screening tests. These biomarkers are plasma lipids: high-density lipoprotein (HDL-C), lowdensity lipoprotein (LDL-C), Total serum cholesterol, total cholesterol/HDL ratio, triglycerides, 24Shydroxycholesterol (24S-HC), lipoprotein A, phospholipids, and sphingolipids. It is better to test this entire panel of biomarkers, as a single biomarker will not help detect a complex condition, such as Alzheimer's disease. Many recent research pieces have found a link between plasma lipids and Alzheimer's disease [1215]. The brain has very high lipid content; hence changes in the brain phospholipids and cholesterol levels can easily lead to pathology in the brain $[16,17]$.

The blood-brain barrier (BBB) prevents the entry of circulating cholesterol into the brain. The brain produces cholesterol from the astrocytes, which is later converted to 24S-hydroxycholesterol. 24S-Hydroxycholesterol can cross the blood-brain barrier and is excreted via the bile from the plasma [5]. In the case of hyperlipidemia, increased plasma cholesterol leads to the formation of free radicals, which disrupt the blood-brain barrier and lead to increased cholesterol in the brain. Cholesterol plays a key role in amyloidogenesis in the brain, causing more beta-amyloid plaques formation and leading to neurodegeneration. ApoE4 is a carrier for cholesterol transport; hence an individual carrying an allele of ApoE4 is prone to developing Alzheimer's [5,6]. Many other genetic mutations of the receptors and transporters involved in cholesterol metabolism and transport, such as ATP binding cassette transporter 1 and 7 (ABCA1, ABCA7), APP have caused Alzheimer's disease [8].

This study aims to show the relationship between plasma lipids and Alzheimer's disease, to demonstrate if increased plasma cholesterol increases the risk for Alzheimer's disease. It will help us understand if these plasma lipid biomarkers can be used as (1) diagnostic biomarker - to evaluate the risk of the onset of $\mathrm{AD}$ and (2) monitoring biomarkers - to estimate the progression of the condition. We will also discuss the various genetic variants associated with the onset of Alzheimer's disease.

\section{Review}

\section{Method}

This systematic review strictly follows the Preferred Reporting Items for Systematic Reviews and MetaAnalyses (PRISMA) guidelines [18]. For data collection, we searched multiple electronic databases, such as PubMed, Google Scholar, Medline, ScienceDirect, PubMed Central, and Web of Science and the website of Neuropathology. Data were collected in September 2020. We used keywords such as "Alzheimer's disease," "cognitive impairment," "plasma lipid biomarkers," "cholesterol," "brain cholesterol metabolism" separately and in combination with each other. We found 3,417 articles with the help of these keywords. The articles' screening was done by going through the topics and abstracts and keeping the ones relevant to our research question. Inclusion and exclusion criteria were applied, and articles were further narrowed down to relevant ones. We did the quality appraisal of all the reference articles by following guidelines, and good quality forty-nine articles were kept.

\section{Inclusion Criteria}

Study selection included the following criteria: studies conducted in English, on humans over 40 years of age, in the last 20 years, that were relevant to our topic and research question, peer-reviewed, full texts, including these study types - clinical trials, observation studies (case-control, cohort, and cross-sectional studies), systematic review, meta-analysis and literature review.

\section{Exclusion Criteria}

Grey literature, books, letter to editor, editorials, duplicate and overlapping studies, in vitro or animal studies.

\section{Result}

A total number of 3,417 studies were identified from the databases. Filters applied based on inclusion criteria (full-text studies in English, last 20 years, on humans, clinical trials, all types of reviews, observational studies), and studies were filtered and reduced to 246 . Screening of the articles was done, and relevant studies kept - 54. Quality appraisal was done for all studies, and the number of studies included reduced to 48. These included 11 systematic reviews/meta-analyses, 12 literature reviews, two randomized control trials, 13 case-control studies, seven cohort studies, and three cross-sectional studies. One article from the 
website of Neuropathology was included. A total of 49 articles were studied [1-49]. This study includes 37 studies that proved the relationship between increased plasma cholesterol, triglycerides, $24 \mathrm{~S}$

hydroxycholesterol, 270 hydroxycholesterol, sphingolipids and phospholipids, and Alzheimer's disease. Twelve studies prove that genetic mutations in ApoE, ApoB, ApoA, ABCA1, ABCA7, APP, and PSEN 1 and PSEN2 alleles are associated with AD. Seven studies explain the metabolism of cholesterol in the brain and the pathology associated with $\mathrm{AD}$ (Figure 1).
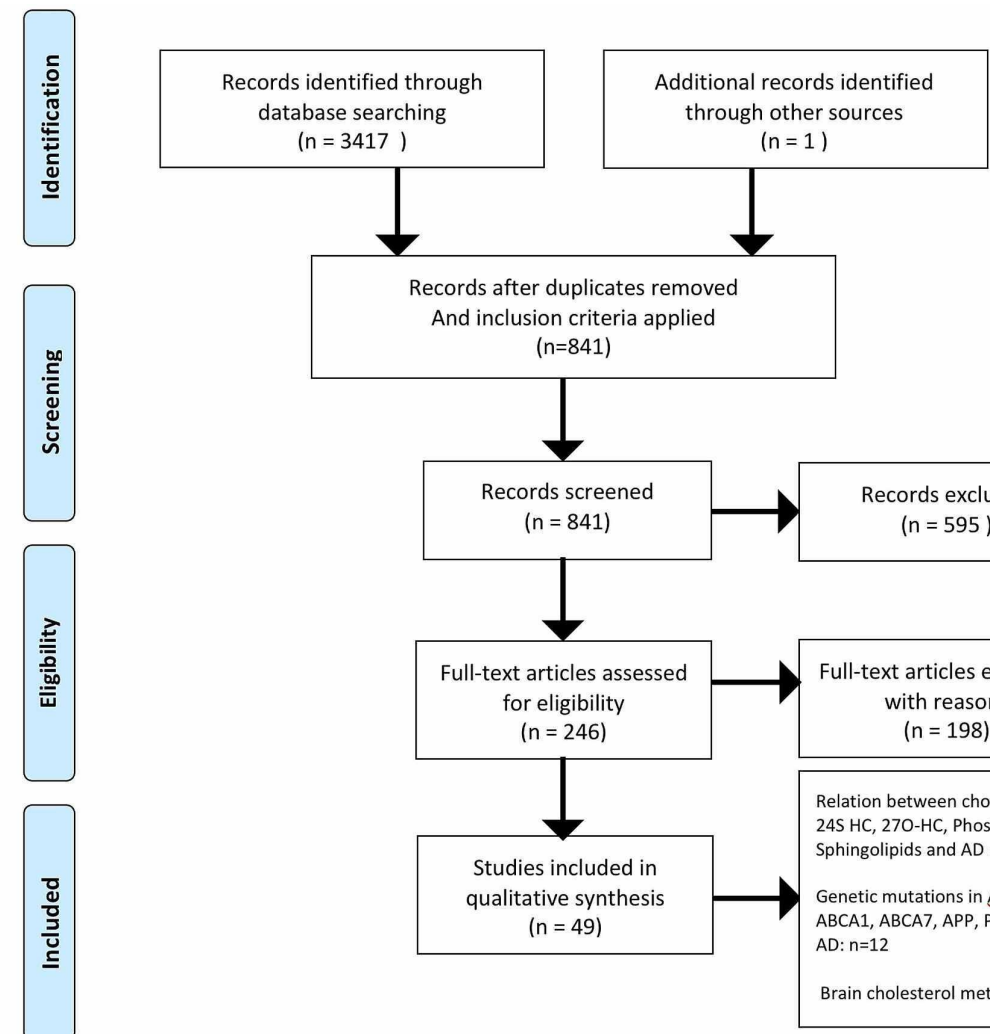
$(n=3417)$ $(n=1)$
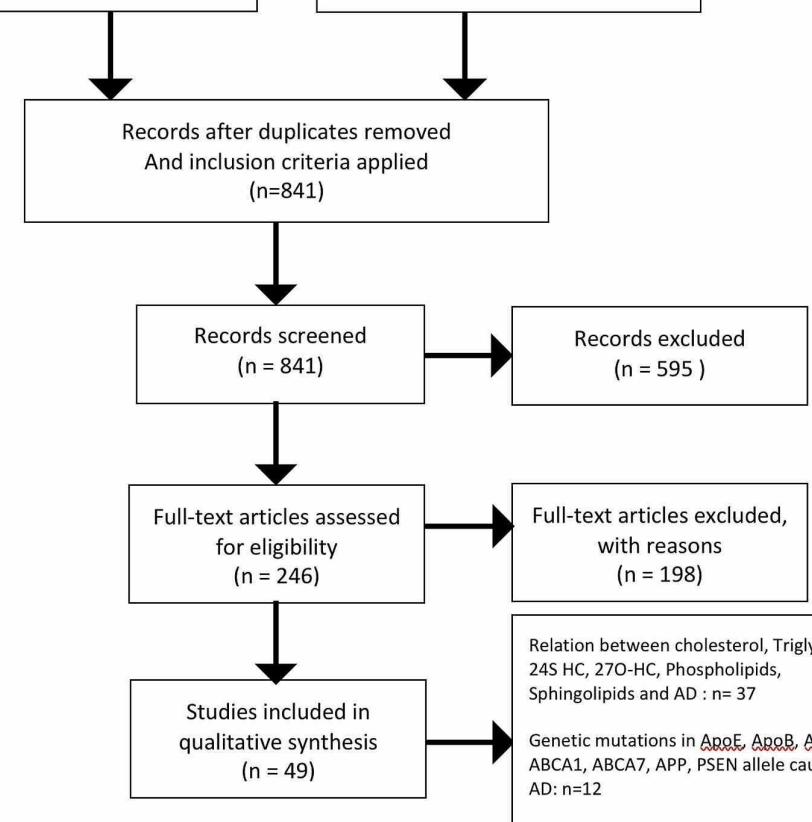

Relation between cholesterol, Triglycerides, 24S HC, 27O-HC, Phospholipids, phingolipids and $A D: n=37$

Genetic mutations in ARoE, ARo, AnoA, ABCA1, ABCA7, APP, PSEN allele causing $A D: n=12$

Brain cholesterol metabolism in AD: $n=7$

\section{FIGURE 1: PRISMA flow chart}

PRISMA: Preferred Reporting Items for Systematic Reviews and Meta-Analyses; AD: Alzheimer's disease, APO: apolipoprotein, APP: amyloid precursor protein; 24S HC: 24 S hydroxycholesterol; 27O-HC: 270 hydroxycholesterol; PSEN: presenilin; ABCA1 and ABCA7: ATP binding cassette transporter 1 and 7

\section{Discussion}

We studied 49 previously published articles, some stressing the association between Alzheimer's disease and plasma lipids and some about the genetic variants of various cholesterol transporters causing AD. In this study, we found that a dysregulation of brain lipid homeostasis can lead to cognitive disorders such as Alzheimer's disease. The exact pathway by which certain mutations happen is still not clear and more research is needed to confirm that.

Cholesterol Metabolism in the Brain and Pathology Related to $A D$

The brain has a rich lipid content. The majority of cholesterol in the central nervous system (CNS) is present in two places; one is the oligodendrocytes of the myelin sheath, and the other is the plasma membrane of astrocytes and neurons. Myelin comprises 70\% lipids containing cholesterol, sphingolipids, and phospholipids [19]. Cholesterol, sphingolipids are essential components of the neuronal plasma membrane present in the form of lipid rafts. It participates in signal transduction, neurotransmitter release, synaptogenesis, and membrane trafficking [11,20]. It is believed that the developing brain produces a high level of cholesterol, but this gradually reduced in the adult brain. The adult brain synthesizes cholesterol by the astrocytes, then transported to the neurons to carry out its functions.

Cholesterol metabolism in the brain depends on brain cells' synthesis, transport across the cells, BBB, and catabolism [5]. Neurons depend on glial cells (astrocytes) for cholesterol. Astrocytes synthesize cholesterol from acetyl CoA by the HMG-CoA reductase enzyme. The transport of cholesterol to neural cells takes place with the help of ApoE which is also synthesized by astrocytes. The ApoE-cholesterol complex is transported with ABCA-1 and is taken up by the neurons via endocytosis through the LDL receptor-related protein (LRP- 
1) [5]. The endocytosed cholesterol in the neuron is further hydrolyzed to form free cholesterol. Free cholesterol undergoes esterification with acyl-coenzyme A cholesterol acyltransferase to form cholesterol esters stored in the neuron's cytoplasm. Some of the free cholesterol also controls the expression of cholesterol synthesizing enzymes and lipoprotein receptors such as liver X receptors (LXRs). These LXRs lead to increased expression of the ABCA1, thus mediating the transport of cholesterol from cells to apolipoproteins [5,6]. There is no degradation mechanism for any excess cholesterol in the brain. The excess cholesterol is converted to $24 \mathrm{~S}$-HC by the cytochrome P450 family 46 subfamilies A member 1 (CYP46A1) enzyme and is transported out of the brain to the blood-brain barrier [21].

The pathognomonic feature of $\mathrm{AD}$ is the building up of beta-amyloid plaques in the brain. In a healthy brain, the beta-secretase/beta-site amyloid precursor protein cleavage enzyme -1 (BACE-1) and gamma-secretase are present in the lipid rafts of the neuronal plasma membrane and cause cleavage of APP forming betaamyloid. However, in AD, increased cholesterol lipid rafts induce raft clustering and enhance BACE-1 and APP interaction leading to increased beta-amyloid production [5,20,22].

The BBB maintains CNS homeostasis by regulating the transport of solutes between blood and brain. The BBB allows diffusion of oxygen and carbon dioxide freely, although lipophilic molecules such as cholesterol enter through receptors or channels. The brain lipid nature's homeostatic balance helps in controlled betaamyloid production by APP cleavage, maintains the receptor channels, vesicle formation, secretion, signaling, inflammation, oxidation, membrane biosynthesis, and remodeling. Dysregulation in the brain lipid environment attributes to disturbed BBB, abnormal APP processing, abnormal cytosis, signaling, increased inflammation, oxidation. Long term, these can result in neuronal death, leading to AD (Figure 2) $[22]$.
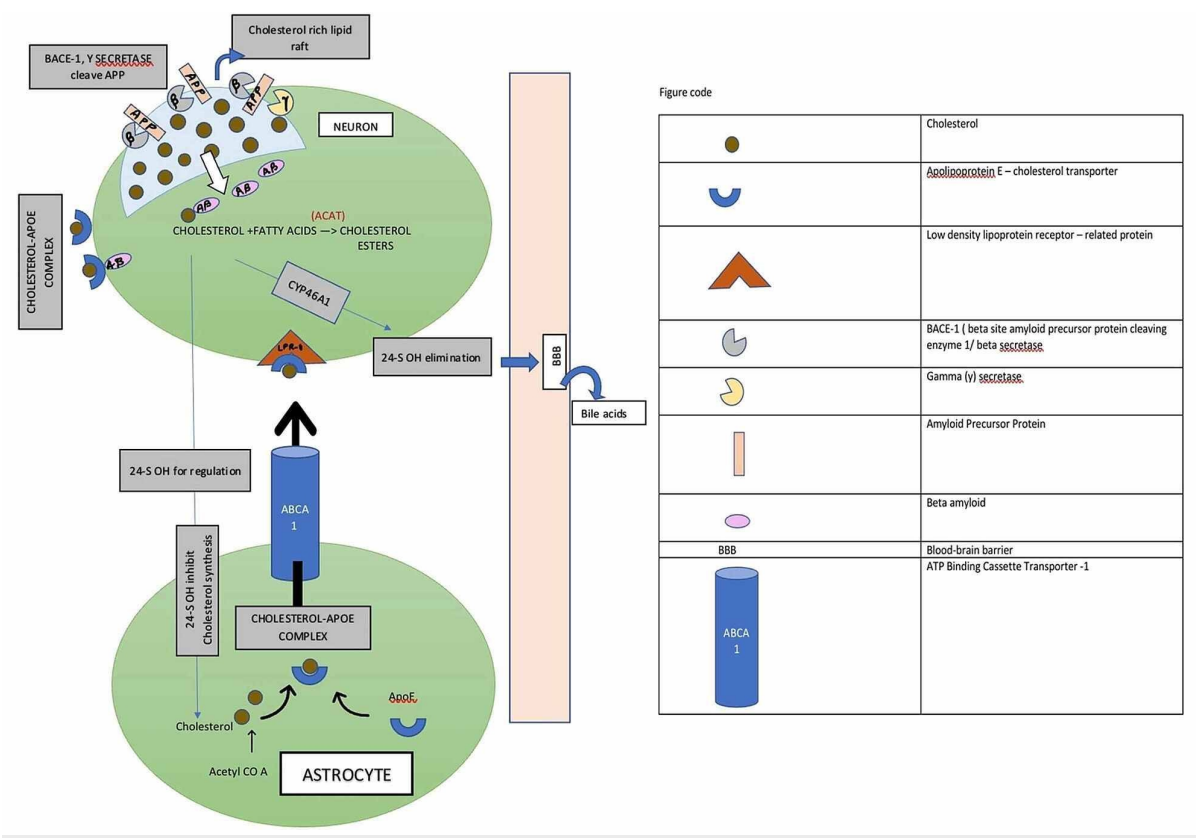

\section{FIGURE 2: Demonstrating the process of synthesis, metabolism, and transport of brain cholesterol}

The Relation Between Plasma Lipids and AD

Many researchers have found a link between cholesterol homeostasis and $\mathrm{AD}$; however, the exact pathogenesis remains unclear. We know that brain is rich in cholesterol content. The cholesterol in the brain and periphery are two separate units as they are well separated by a blood barrier, which restricts the entry of peripheral cholesterol. The cholesterol present in the lipid rafts of plasma neuronal membrane causes cleavage of APP. In the case of increased cholesterol in the lipid rafts, cholesterol enhances the activity of BACE-1 and Gamma-secretase and causes cleavage of APP leading to increased beta-amyloid production. These beta-amyloid plaques are characteristic hallmarks of AD. Increased plasma LDL-C, TC, triglycerides (TG), and decreased HDL-C was associated with increased beta-amyloid plaques causing AD. A cohort study by Pappolla et al. emphasized the association between high plasma cholesterol and patients with $\mathrm{AD}$ [23]. They found that increased cholesterol in the plasma was leading to increased beta-amyloid production. Many other studies found the same association between cholesterol and beta-amyloid plaques in the brain $[4,24]$. Some studied proved that beta-amyloid isoforms 1-40, 1-42 are associated explicitly with plasma cholesterol [7,13]. The study by Iqbal et al. was a systematic review showing that increased LDL-C, TC, TG were increasing beta-amyloid production. In contrast, decreased HDL-C was associated with AD [24]. 
Apart from amyloid plaques, $\mathrm{AD}$ is also associated with atrophy of the left/right hippocampal and entorhinal cortex. These changes are seen in the early stage of $\mathrm{AD}$ even before symptoms could arise. A case-control study by Proitsi et al., including 300 patients, also found that increased plasma lipids led to amyloid plaques in the brain and hippocampal and entorhinal cortex atrophy patients with $\mathrm{AD}[25]$. Another study by Wolf et al. also studied the hippocampal atrophy of the brain and found its link with cholesterol; however, it was only associated with HDL-C [26]. The role of HDL-C in the disease process of AD is controversial. HDL is found to reduce the build-up of beta-amyloid plaques, thus reducing inflammation. Many researchers studied this protective role of HDL-C. Formiga et al. included 321 patients in a cohort study and proved the association between decreased HDL and $\mathrm{AD}$ [27]. Few other studies also proved the same objective $[26,28]$. Physical activity can decrease HDL levels and has proven to improve symptoms and progression of $\mathrm{AD}$ by a randomized control trial of 170 patients [28].

Cholesterol and triglycerides are also known to be a predictive marker for cardiovascular diseases. These lipids build up and obstruct the arteries supplying the heart. A similar mechanism was assumed for AD. Scientists believed that AD happens due to the brain's poor oxygenation due to the lipids' clogged vessels. Some studies determined the relation between these serum lipids and $\mathrm{AD}$ and if it is similar to the cardiac risk profile. A cohort study of nearly 4000 subjects by Helzner et al. shows that plasma lipids are associated with AD and other vascular diseases [29]. However, the mini-mental state exam (MMSE) was not affected, and hence it is still unclear how the cardiac risk profile affects cognition [15,30]. The relation between cholesterol and low MMSE was seen in a study by Hall et al. [31].

Unlike the studies already discussed, some studies say that only TC has an association with AD. The theory remains unclear, though. A study by He et al. proved that LDL, HDL, and triglycerides levels remain normal and only increased TC was seen in AD [32]. He included 130 patients in his case-control study. Similar studies by other authors also proved the same concept [33,34]. These studies by Solomon et al. and Anstey et al. suggest that total cholesterol has a bidirectional association with AD. It was seen to rise to midlife, suggesting cognitive impairment, and later declined with age in patients with AD. Solomon et al. proved this by conducting a large-scale case-control study, including 1321 patients with AD and 1203 controls [34]. Some other studies also found that only a single lipoprotein- low-density lipoprotein was elevated in $\mathrm{AD}$, serum levels of rest were normal.

LDL-C is seen to cause vascular and neurotoxic effects in the brain $[35,36]$. Another study by Zhon, a systematic review including nearly 6500 patients, found the same association; however, LDL-C was high in patients with $\mathrm{AD}$ mostly around 60-70 years of age, gradually reduced with ageing [37]. Some studies found an association between AD and only LDL-C, TC. Many hypotheses are present. Some say LDL-C, TC is associated with increased tau concentration, according to some LDL-C, TC cause increased amyloid buildup, and some found that LDL and TC disrupt the cell cycle [38]. A study by Liu et al., including around 2333 $\mathrm{AD}$ patients and 3615 healthy controls, also suggested the association between LDL-C, TC, and AD [39]. Two studies also found that cholesterol remains normal, and only the serum triglyceride level is increased in the case of $\mathrm{AD}[22,40]$.

It is known that de novo synthesis of cholesterol occurs in the brain, and any disruption in this mechanism can lead to AD. 24S Hydroxycholesterol is the elimination product of neuronal cholesterol that leaves the brain and enters the periphery by crossing the BBB. 24S-HC and 270 hydroxycholesterol in the plasma indicates the degree of beta-amyloid production, loss of active grey matter, phosphorylated tau accumulation, and brain atrophy, thus indicating $\mathrm{AD}$ [11]. A case-control study by Popp et al., including 200 patients, found an association between increased plasma $24 \mathrm{~S}$ hydroxycholesterol, $27 \mathrm{O}$ hydroxycholesterol, and $\mathrm{AD}$ [41]. Another study also showed a similar association [30].

Another group of lipids associated with AD is the sphingolipids and phospholipids. Sphingolipids such as sphingomyelin, ceramide, sulfatide, and sphingosine are major constituents of the neuron's plasma membrane. They are present in the lipid rafts, hence have a role in enhancing the activity of BACE- 1 and gamma-secretase that causes cleavage of APP, forming beta-amyloid [20]. Phospholipids such as phosphatidylcholine, plasmogens, phosphatidylinositol, too, are a part of the membrane-forming lipid [20]. An association between serum and CSF levels of sphingolipids and phospholipids and AD has been studied. A study by Wong et al. showed that CSF sphingomyelin levels increase in the prodromal stage in AD, CSF ceramide increases in AD, CSF sulfatide levels decrease in AD, CSF phospholipids levels also increase. Whereas in the blood, ceramide level increases, sphingomyelin levels decrease, and phospholipids decrease in $\mathrm{AD}$ [20]. Another study by Kosicek et al. also found similar results [17]. A case-control study by Costa et al. studied ten membrane phospholipids and their association with $\mathrm{AD}$. These were found to decrease in $\mathrm{AD}$ (Table 1) [42].

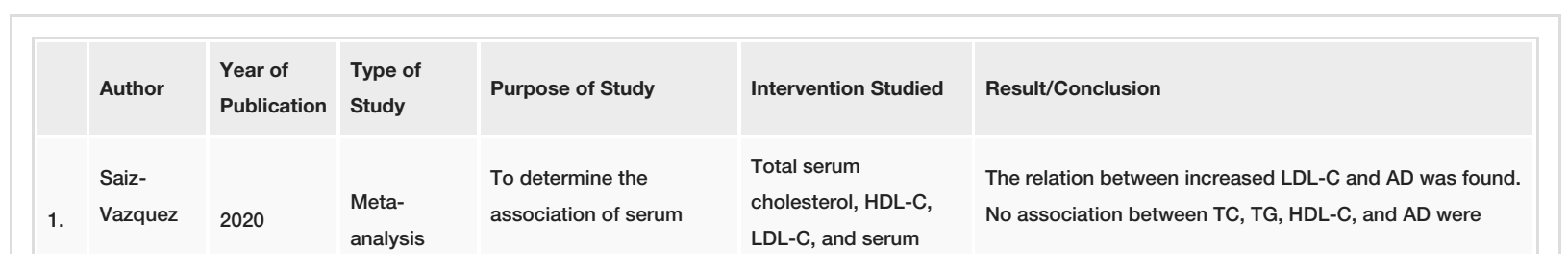




\section{Cureus}

\begin{tabular}{|c|c|c|c|c|c|c|}
\hline & et al. [35] & & & cholesterol and AD. & triglycerides & found. \\
\hline 2. & $\begin{array}{l}\text { Zhou et } \\
\text { al. [37] }\end{array}$ & 2020 & $\begin{array}{l}\text { A } \\
\text { systematic } \\
\text { review and } \\
\text { meta- } \\
\text { analysis }\end{array}$ & $\begin{array}{l}\text { To determine the } \\
\text { association of serum } \\
\text { cholesterol and } A D \text {. }\end{array}$ & LDL-C was measured & $\begin{array}{l}\text { Elevated LDL-C leads to AD. This association is more in } \\
\text { patients } 60-70 \text { years of age and gradually declines with } \\
\text { age. }\end{array}$ \\
\hline 3. & $\begin{array}{l}\text { lqbal et al. } \\
\text { [24] }\end{array}$ & 2020 & $\begin{array}{l}\text { Systematic } \\
\text { review }\end{array}$ & $\begin{array}{l}\text { To determine the } \\
\text { association of serum } \\
\text { lipids and } A D\end{array}$ & HDL-C, LDL-C, TG, TC & $\begin{array}{l}\text { HDL-C was found to be low, whereas LDL-C, TG, TC were } \\
\text { high in cases of AD. }\end{array}$ \\
\hline 4. & $\begin{array}{l}\text { Bernath et } \\
\text { al. [40] }\end{array}$ & 2020 & $\begin{array}{l}\text { Cross- } \\
\text { sectional } \\
\text { study }\end{array}$ & $\begin{array}{l}\text { To determine the } \\
\text { association of } \\
\text { triglycerides with } A D\end{array}$ & Serum IG & Serum IG was found to be high in cases of AD \\
\hline b. & $\begin{array}{l}\text { Jensen et } \\
\text { al. [28] }\end{array}$ & 2020 & $\begin{array}{l}\text { Randomized } \\
\text { control trial }\end{array}$ & $\begin{array}{l}\text { To determine if physical } \\
\text { exercise influences the } \\
\text { lipid profile and } A D\end{array}$ & $\begin{array}{l}\mathrm{HDL}-\mathrm{C}, \mathrm{TC}, \mathrm{LDL}-\mathrm{C} \text {, } \\
\text { triglycerides }\end{array}$ & $\begin{array}{l}\text { With an increase in physical activity, cholesterol was } \\
\text { lower, thus decreasing the risk of AD. }\end{array}$ \\
\hline 6. & $\begin{array}{l}\text { Chew et } \\
\text { al. [22] }\end{array}$ & 2020 & $\begin{array}{l}\text { Literature } \\
\text { review }\end{array}$ & $\begin{array}{l}\text { To determine the factors } \\
\text { affecting lipid } \\
\text { metabolism and the } \\
\text { association between } \\
\text { plasma lipids and AD. }\end{array}$ & $\begin{array}{l}\text { Age, sex, race, diet, } \\
\text { plasma lipids level }\end{array}$ & $\begin{array}{l}\text { Decreased plasma HDL-C and increased triglyceride is } \\
\text { associated with AD. }\end{array}$ \\
\hline 7. & $\begin{array}{l}\text { Liu et al. } \\
\text { [39] }\end{array}$ & 2019 & $\begin{array}{l}\text { Meta- } \\
\text { analysis }\end{array}$ & $\begin{array}{l}\text { To determine the } \\
\text { association between } \\
\text { plasma cholesterol and } \\
\mathrm{AD}\end{array}$ & $\begin{array}{l}\text { Total serum } \\
\text { cholesterol, HDL-C, } \\
\text { LDL-C, and serum } \\
\text { triglycerides }\end{array}$ & $\begin{array}{l}\text { elevated in AD. No association between HDL-C and } \\
\text { triglycerides was found. }\end{array}$ \\
\hline 8. & W38] & 2019 & $\begin{array}{l}\text { Meta- } \\
\text { analysis }\end{array}$ & $\begin{array}{l}\text { To determine the } \\
\text { association between } \\
\text { plasma lipids and } A D\end{array}$ & HDL-C, TC, LDL-C & LDL-C, TC are increased in AD \\
\hline 9. & $\begin{array}{l}\text { Costa et } \\
\text { al. [42] }\end{array}$ & 2019 & $\begin{array}{l}\text { Case- } \\
\text { control } \\
\text { study }\end{array}$ & $\begin{array}{l}\text { To determine the } \\
\text { association between } \\
\text { phospholipids and AD, } \\
\text { and the activity of PLA2 } \\
\text { in the brain }\end{array}$ & $\begin{array}{l}\text { Serum phospholipids, } \\
\text { PLA2 by radio } \\
\text { enzymatic assay }\end{array}$ & $\begin{array}{l}\text { Ten serum phospholipids were assessed and found to } \\
\text { decrease in AD; PLA2 activity was also decreased in the } \\
\text { neuronal membrane in AD. }\end{array}$ \\
\hline 10. & $\begin{array}{l}\text { Anstey et } \\
\text { al. [34] }\end{array}$ & 2017 & $\begin{array}{l}\text { A } \\
\text { systematic } \\
\text { review and } \\
\text { meta- } \\
\text { analysis }\end{array}$ & $\begin{array}{l}\text { association between } \\
\text { plasma lipids and } A D \text { in } \\
\text { midlife }\end{array}$ & HDL-C, LDL-C, TC, TG & $\begin{array}{l}\text { Increased TC in midlife is found to be associated with } \\
\text { late-onset AD. No association between HDL and TG with } \\
\text { AD was found. }\end{array}$ \\
\hline 11. & $\begin{array}{l}\text { Proitsi et } \\
\text { al. [25] }\end{array}$ & 2017 & $\begin{array}{l}\text { Case- } \\
\text { control } \\
\text { study }\end{array}$ & $\begin{array}{l}\text { To determine the } \\
\text { association between } \\
\text { plasma cholesterol and } \\
A D \text { and the associated } \\
\text { brain atrophy }\end{array}$ & $\begin{array}{l}\text { Plasma lipids. Brain - } \\
\text { left/right hippocampal } \\
\text { area, entorhinal cortex }\end{array}$ & $\begin{array}{l}\text { Increased plasma lipids were associated with } A D \text {, causing } \\
\text { brain atrophy. }\end{array}$ \\
\hline 12. & $\begin{array}{l}\text { Wong et } \\
\text { al. [20] }\end{array}$ & 2017 & $\begin{array}{l}\text { Literature } \\
\text { review }\end{array}$ & $\begin{array}{l}\text { To determine the } \\
\text { progress in lipidomics } \\
\text { research in AD with the } \\
\text { help of mass } \\
\text { spectrometry }\end{array}$ & $\begin{array}{l}\text { Phospholipids, } \\
\text { sphingolipids, and } \\
\text { cholesterol }\end{array}$ & $\begin{array}{l}\text { Increase total cholesterol increase the risk of AD. } \\
\text { Sphingolipids: in CSF - sphingomyelin levels increase in } \\
\text { prodromal AD, ceramide increases in AD, sulfatide } \\
\text { decreases in AD. As blood - ceramide level increases, } \\
\text { sphingomyelin decreases in AD. Phospholipids: increases } \\
\text { in CSF and decreases in blood in AD. }\end{array}$ \\
\hline 13. & $\begin{array}{l}\text { Wang et } \\
\text { al. [11] }\end{array}$ & 2016 & $\begin{array}{l}\text { Meta- } \\
\text { analysis }\end{array}$ & $\begin{array}{l}\text { To determine if } 24 \mathrm{~S}-\mathrm{HC} \\
\text { and } 27 \mathrm{O} \mathrm{HC} \text { are } \\
\text { biomarkers for } \mathrm{AD}\end{array}$ & 24S-HC, 27S-HC & $\begin{array}{l}24 \mathrm{~S}-\mathrm{HC} \text { and } 27 \mathrm{O}-\mathrm{HC} \text { are sensitive biomarkers for } \mathrm{AD} \\
\text { diagnosis }\end{array}$ \\
\hline 14. & $\begin{array}{l}\text { He et al. } \\
\text { [32] }\end{array}$ & 2016 & $\begin{array}{l}\text { Case- } \\
\text { control } \\
\text { study }\end{array}$ & $\begin{array}{l}\text { To determine the } \\
\text { association of plasma } \\
\text { lipids with } \mathrm{MCl} \text { in the } \\
\text { elderly }\end{array}$ & $\begin{array}{l}\text { Total cholesterol, } \\
\text { HDL-C, LDL-C, serum } \\
\text { triglycerides were } \\
\text { measured }\end{array}$ & $\begin{array}{l}\text { TC was elevated in the elderly with AD. No association } \\
\text { between LDL-C and AD was found. HDL-C and TG were } \\
\text { negatively related to AD. }\end{array}$ \\
\hline & Hall et al. & & Systematic & & Total serum & \\
\hline
\end{tabular}




\section{Cureus}

\begin{tabular}{|c|c|c|c|c|c|c|}
\hline 15. & [31] & 2014 & review & $\begin{array}{l}\text { cholesterol in AD is } \\
\text { gender-specific }\end{array}$ & cholesterol & Males were found to have higher total Cholesterol in AD \\
\hline 16. & $\begin{array}{l}\text { Toro et al. } \\
{[44]}\end{array}$ & 2014 & $\begin{array}{l}\text { Cohort } \\
\text { study }\end{array}$ & $\begin{array}{l}\text { To determine the } \\
\text { association of total } \\
\text { cholesterol in } \mathrm{AD} \text { and } \\
\mathrm{MCl} \text { and the ApoE } \\
\text { genotype }\end{array}$ & Total cholesterol & $\begin{array}{l}\text { Increased TC is seen in patients with } \mathrm{MCl} \text { and } \mathrm{AD} \text { even } \\
\text { before symptom scan arise. This is independent of the } \\
\text { APOE genotype. }\end{array}$ \\
\hline 17. & Lukiw [49] & 2014 & $\begin{array}{l}\text { Literature } \\
\text { review }\end{array}$ & $\begin{array}{l}\text { To determine if } \\
\text { cholesterol and } 24 \\
\text { hydroxycholesterol } \\
\text { trafficking in the brain } \\
\text { causes AD and CYP46A1 } \\
\text { gene effects on AD }\end{array}$ & $\begin{array}{l}\text { Cholesterol and } 24 \\
\text { hydroxycholesterol, } \\
\text { beta-amyloid plaques, } \\
\text { CYP46A1 genotyping }\end{array}$ & $\begin{array}{l}\text { Beta-amyloid plaques, which is characteristic of AD, were } \\
\text { found with increased CSF } 24 \text { hydroxycholesterol, a } \\
\text { mutation in the CYP46A1 gene causes dysfunctional } \\
\text { cholesterol metabolism }\end{array}$ \\
\hline 18. & $\begin{array}{l}\text { Reitz and } \\
\text { Mayeux } \\
{[4]}\end{array}$ & 2014 & $\begin{array}{l}\text { Literature } \\
\text { review }\end{array}$ & $\begin{array}{l}\text { To determine the genetic } \\
\text { and non-genetic risk } \\
\text { factor of } A D\end{array}$ & $\begin{array}{l}\text { Plasma and CSF lipid } \\
\text { markers, genetic } \\
\text { mutations, age, } \\
\text { physical activity, BMI, } \\
\text { cerebrovascular } \\
\text { disease. }\end{array}$ & Cholesterol was found to be increased in cases of AD. \\
\hline 19. & $\begin{array}{l}\text { Popp et } \\
\text { al. [41] }\end{array}$ & 2013 & $\begin{array}{l}\text { Case- } \\
\text { control } \\
\text { study }\end{array}$ & $\begin{array}{l}\text { To determine the } \\
\text { association between } \\
\text { cerebral and } \\
\text { extracerebral cholesterol } \\
\text { and its relation with AD. }\end{array}$ & $\begin{array}{l}\text { Plasma and CSF } \\
\text { cholesterol, } \\
\text { cholesterol } \\
\text { precursors, } 24 \\
\text { hydroxycholesterols, } \\
\text { and } 27 \\
\text { hydroxycholesterols } \\
\text { were measured. }\end{array}$ & $\begin{array}{l}\text { Cholesterol synthesis was found to be de novo in the } \\
\text { brain. Twenty-four hydroxycholesterols were found to } \\
\text { increase in the case of } A D \text {. }\end{array}$ \\
\hline 20. & $\begin{array}{l}\text { Kosicek } \\
\text { and } \\
\text { Hecimovic } \\
{[17]}\end{array}$ & 2013 & $\begin{array}{l}\text { Literature } \\
\text { review }\end{array}$ & $\begin{array}{l}\text { To determine the } \\
\text { association between } \\
\text { phospholipids and AD }\end{array}$ & $\begin{array}{l}\text { Sulfatide, ceramide, } \\
\text { sphingomyelin, PC }\end{array}$ & $\begin{array}{l}\text { Sphingomyelin increases in the prodromal stage of AD, } \\
\text { ceramide increases, Sulfatide decreases, and PC } \\
\text { metabolites decreased in AD. }\end{array}$ \\
\hline 21. & $\begin{array}{l}\text { Formiga } \\
\text { et al. [27] }\end{array}$ & 2012 & $\begin{array}{l}\text { Cohort } \\
\text { study }\end{array}$ & $\begin{array}{l}\text { To determine the } \\
\text { association of HDL-C } \\
\text { levels with mental, } \\
\text { physical activity, and } \\
\text { cognition }\end{array}$ & HDL-C & $\begin{array}{l}\text { Decreased HDL-C was only found to improve functional } \\
\text { aspect but not cognitive performance }\end{array}$ \\
\hline 22. & $\begin{array}{l}\text { Helzner } \\
\text { et al. [29] }\end{array}$ & 2009 & $\begin{array}{l}\text { Cohort } \\
\text { study }\end{array}$ & $\begin{array}{l}\text { To determine the role of } \\
\text { vascular risk factors in } \\
\text { AD. }\end{array}$ & $\begin{array}{l}\text { Total cholesterol, } \\
\text { HDL-C, LDL-C }\end{array}$ & $\begin{array}{l}\text { High total cholesterol and LDL-C levels and diabetes } \\
\text { cause an increased incidence of } A D \text {, thus confirming that } \\
\text { vascular risk factors play a role in } A D \text {. }\end{array}$ \\
\hline 23. & $\begin{array}{l}\text { Mamo et } \\
\text { al. [13] }\end{array}$ & 2008 & $\begin{array}{l}\text { Case- } \\
\text { control } \\
\text { study }\end{array}$ & $\begin{array}{l}\text { To investigate if } \\
\text { lipoproteins are bound to } \\
A \beta \text { isoforms }\end{array}$ & $\begin{array}{l}\text { Fasting state } \\
\text { lipoproteins }\end{array}$ & $\begin{array}{l}\text { The majority of plasma triglycerides, VLDL, and IDL, was } \\
\text { bound to } A \beta_{1-40} \text { isoform }\end{array}$ \\
\hline 24. & $\begin{array}{l}\text { Solomon } \\
\text { et al. [33] }\end{array}$ & 2007 & $\begin{array}{l}\text { Case- } \\
\text { control } \\
\text { study }\end{array}$ & $\begin{array}{l}\text { To determine the } \\
\text { association between TC } \\
\text { and } A D\end{array}$ & TC & $\begin{array}{l}\text { Serum TC increases in midlife in AD and later decreases } \\
\text { with age. }\end{array}$ \\
\hline 25. & $\begin{array}{l}\text { Raygani } \\
\text { et al. [ } 46]\end{array}$ & 2006 & $\begin{array}{l}\text { Case- } \\
\text { control } \\
\text { study }\end{array}$ & $\begin{array}{l}\text { To determine the } \\
\text { association between } \\
\text { plasma lipids, ApoE } \\
\text { polymorphism, and with } \\
\text { AD }\end{array}$ & $\begin{array}{l}\text { HDL-C, LDL-C, TC, } \\
\text { APOB, APOE4, APOA1 }\end{array}$ & $\begin{array}{l}\text { Apolipoprotein e4 is associated with AD. Also, decreased } \\
\text { apoA1, HDL-C, increased Apo B, increased LDL-C, TC is } \\
\text { seen in AD. }\end{array}$ \\
\hline 26. & $\begin{array}{l}\text { Solfrizzi et } \\
\text { al. [30] }\end{array}$ & 2006 & $\begin{array}{l}\text { Literature } \\
\text { review }\end{array}$ & $\begin{array}{l}\text { To determine the } \\
\text { association between } \\
\text { biomarkers such as HDL- } \\
\mathrm{C}, \mathrm{TC} \text {, LDL-C, } \\
\text { homocysteine, } \\
\text { lipoprotein A, } \\
\text { inflammatory cytokines, } \\
\text { and } \mathrm{AD}\end{array}$ & $\begin{array}{l}\text { HDL-C, LDL-C, TC, } \\
\text { triglycerides, } \\
\text { homocysteine, LP(A), } \\
\text { cytokines }\end{array}$ & $\begin{array}{l}\text { All these biomarkers were found to increase in } \\
\text { association with } A D\end{array}$ \\
\hline
\end{tabular}




\section{Cureus}

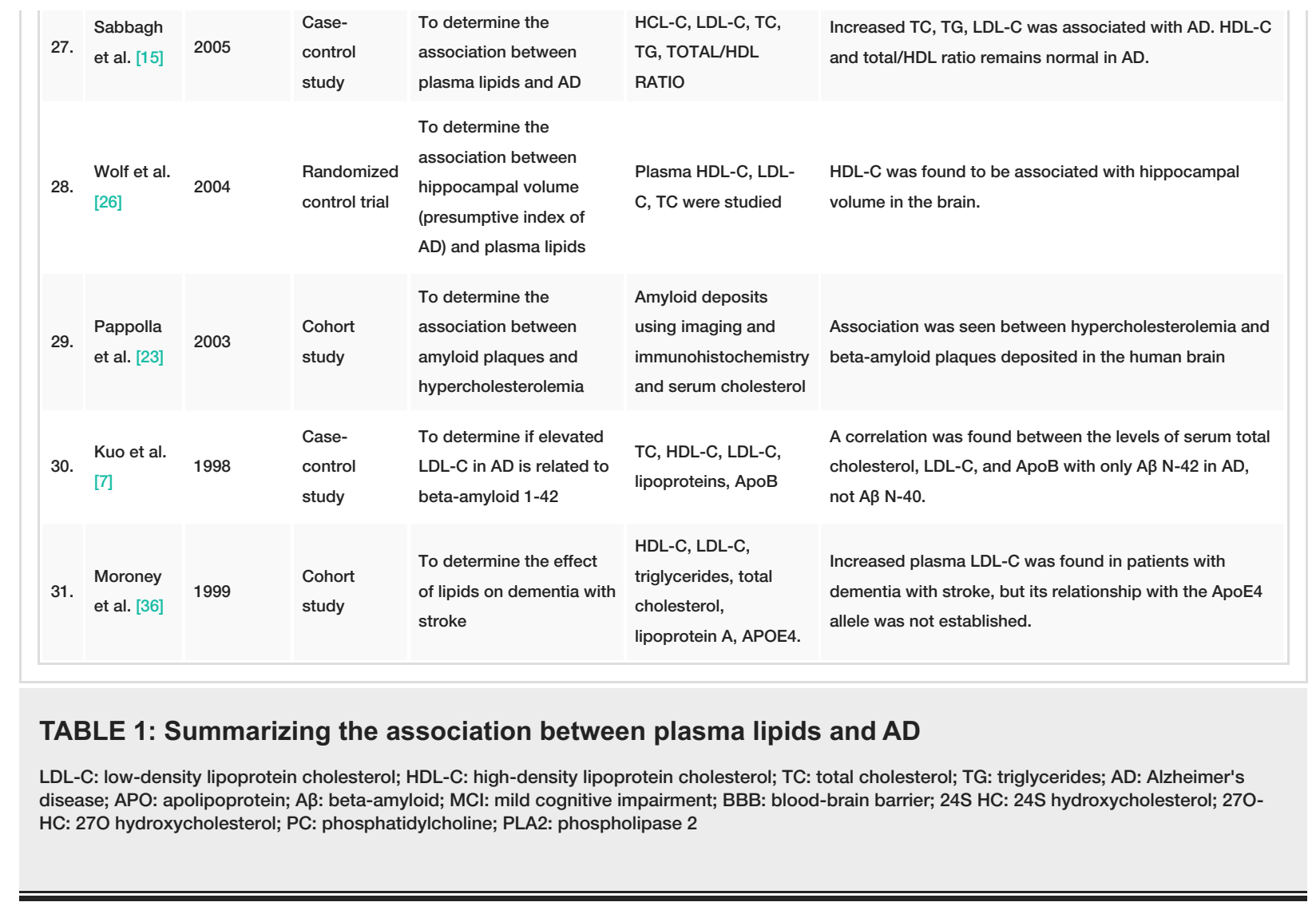

Genetic Mutations in Cholesterol-Related Genes and $A D$

Apolipoprotein E is produced by the astrocytes and is a carrier transport protein, shifting cholesterol from astrocytes to neurons. Apolipoprotein $\mathrm{E}$ also has an affinity for beta-amyloid in the presence of cholesterol. Some studies found that ApoE is required for the clearance of beta-amyloid. Thus, any mutation in this could lead to a decrease in the clearance and building up of plaques [6]. There are three isoforms of ApoE: ApoE2, ApoE3, ApoE4. ApoE3 is the commonest isoform present in the majority of the population; however, ApoE4 has the strongest established association with AD. Any individual homozygous for this allele and old can develop $\mathrm{AD}[6]$. Since it has such a strong association, any mutations in ApoE4 can result in AD. According to studies, ApoE4 is an independent risk factor for AD [10]. A Cohort study by Kivipelto et al., including 1449 $\mathrm{AD}$ patients, suggests that $\mathrm{ApoE} 4$ is an independent risk factor for $\mathrm{AD}$ [43]. Another cohort study by Toro et al. also found the same association [44]. Other isoforms of ApoE are not as closely related to causing AD as ApoE4. ApoE2 does not have any role in $\mathrm{AD}$, and ApoE3 has protective effects against $\mathrm{AD}$. A systematic review by Agarwal et al. suggests the above and found that all alleles of ApoE4 - ApoE 2/4,3/4,4/4 are associated with $\mathrm{AD}[45]$.

Some other types of apolipoproteins are also related to $\mathrm{AD}$. $\mathrm{ApoB}$ is another lipoprotein associated with $\mathrm{AD}$; the exact reason remains unclear. In the brain, most of the cholesterol is present in density similar to that of HDL-C and transported via ApoE or ApoA [5]. Any mutation in the ApoA gene can also cause AD. A study conducted by Raygani et al. found that apart from ApoE 4, increased ApoB and decreased ApoA1 are associated with Alzheimer's disease [46]. Early-onset AD has also been associated with mutations in the genes coded for enzymes and transporters involved in beta-amyloid metabolisms, such as APP, PSEN1, and PSEN2. APP cleaves to form beta-amyloid, and presenilin is a protein present in the gamma-secretase complex [8]. Studies have shown the association between AD and mutation in the gene of APP, PSEN1, PSEN2, and ApoB [47].

Some studies have found the association between another cholesterol transporter - ABCA1 and AD. ABCA1 is essential for the cholesterol efflux from the CSF to the serum. ABCA1 is also found to reduce beta-amyloid accumulation. Lack of gene/defect in the gene of ABCA1 is associated with building up of amyloid plaques, causing $\mathrm{AD}$ [16]. A study by Li et al. studied the association between ABCA1 and Cholesterol efflux causing $\mathrm{AD}$ [48]. The same study also found the association between another genotype, ABCA7, and AD. By the metabolism of cholesterol, we have studied that cholesterol does not cross BBB; hence it is metabolized to $24 \mathrm{~S}$ hydroxycholesterol with the help of the enzyme CYP46A1 and further eliminated via the BBB. Any mutation in the gene coding for CYP46A1 can lead to defects in elimination, causing increased cholesterol and more amyloid plaques leading to AD. A study by Lukiw et al. found the association between $24 \mathrm{~S}-\mathrm{HC}$, cholesterol synthesizing enzyme, and $\mathrm{AD}$ (Table 2, Figure 3) [49]. 


\section{Cureus}

\begin{tabular}{|c|c|c|c|c|c|}
\hline Author & $\begin{array}{l}\text { Year of } \\
\text { Publication }\end{array}$ & $\begin{array}{l}\text { Type of } \\
\text { Study }\end{array}$ & Purpose of Study & Intervention Studied & Result/Conclusion \\
\hline $\begin{array}{l}\text { Wings et } \\
\text { al. [8] }\end{array}$ & 2019 & $\begin{array}{l}\text { Case- } \\
\text { control } \\
\text { study }\end{array}$ & $\begin{array}{l}\text { To determine if plasma } \\
\text { cholesterol and genetic } \\
\text { variants of various } \\
\text { cholesterol transport } \\
\text { proteins are associated with } \\
\text { AD. }\end{array}$ & $\begin{array}{l}\text { Total cholesterol, LDL- } \\
\text { C, HDL-C, TG, and } \\
\text { genetic variants in } \\
\text { ApoB, } \\
\text { ApoE, APP, PSEN1 } \\
\text { and PSEN2. }\end{array}$ & $\begin{array}{l}\text { Primary outcome: the relationship between plasma } \\
\text { cholesterol and AD was seen. Secondary outcome: } \\
\text { AD was associated with mutations in } \\
\text { APOE, APP, PSEN1, PSEN2, and APOB. }\end{array}$ \\
\hline $\begin{array}{l}\text { Jeong et } \\
\text { al. [6] }\end{array}$ & 2019 & $\begin{array}{l}\text { Literature } \\
\text { review }\end{array}$ & $\begin{array}{l}\text { To determine if APOE } \\
\text { induced cholesterol } \\
\text { dysfunction affects the } \\
\text { various brain cells and } \\
\text { causes AD. }\end{array}$ & $\begin{array}{l}\text { APOE4, APOE3, } \\
\text { APOE2 alleles }\end{array}$ & APOE $\varepsilon 4$ one or more alleles increase the risk of $A D$ \\
\hline $\begin{array}{l}\text { Li et al. } \\
\text { [48] }\end{array}$ & 2017 & $\begin{array}{l}\text { Case- } \\
\text { control } \\
\text { study }\end{array}$ & $\begin{array}{l}\text { To determine if the ABCA7 } \\
\text { genotype of cholesterol } \\
\text { transport protein it's } \\
\text { associated with sporadic } \\
\text { AD }\end{array}$ & ABCA7 genotyping & $\begin{array}{l}\text { ABCA7 genotype was associated with lipid } \\
\text { homeostasis and AD. }\end{array}$ \\
\hline $\begin{array}{l}\text { Yassine } \\
\text { et al. [16] }\end{array}$ & 2016 & $\begin{array}{l}\text { Cross- } \\
\text { sectional } \\
\text { study }\end{array}$ & $\begin{array}{l}\text { To determine if } A B C A-1 \\
\text { mediated cholesterol efflux } \\
\text { is affected in patients with } \\
A D \text { and } \mathrm{MCl}\end{array}$ & $\begin{array}{l}\text { CSF's role in } \\
\text { cholesterol transport } \\
\text { was assessed using a } \\
\text { BHK cell line that } \\
\text { expressed the ABCA1 } \\
\text { transporter. }\end{array}$ & $\begin{array}{l}\text { In case of } \mathrm{MCl} \text { and } \mathrm{AD} \text {, the role of CSF was } \\
\text { impaired. } \mathrm{ABCA} 1 \text {-mediated cholesterol efflux does } \\
\text { not take place as normal, leading to } \mathrm{AD} \text {. }\end{array}$ \\
\hline $\begin{array}{l}\text { Agarwal } \\
\text { et al. [45] }\end{array}$ & 2014 & $\begin{array}{l}\text { Meta- } \\
\text { analysis }\end{array}$ & $\begin{array}{l}\text { To determine the } \\
\text { association between ApoE } \\
\text { alleles and the risk for } A D\end{array}$ & APOE genotyping & $\begin{array}{l}\text { All genotypes of the ApoE e } 4 \text { allele, increase the } \\
\text { risk of } A D \text {, although the } A p o E \text { e2, e } 3 \text { alleles protect } \\
\text { from } A D \text {. }\end{array}$ \\
\hline $\begin{array}{l}\text { Toro et } \\
\text { al. [44] }\end{array}$ & 2014 & $\begin{array}{l}\text { Cohort } \\
\text { study }\end{array}$ & $\begin{array}{l}\text { To determine the } \\
\text { association of total } \\
\text { cholesterol in } A D \text { and } M C I \\
\text { and the ApoE genotype }\end{array}$ & Total cholesterol & $\begin{array}{l}\text { High TC levels are associated with AD but are } \\
\text { independent of the APOE genotype. }\end{array}$ \\
\hline $\begin{array}{l}\text { Lukiw } \\
\text { [49] }\end{array}$ & 2014 & $\begin{array}{l}\text { Literature } \\
\text { review }\end{array}$ & $\begin{array}{l}\text { To determine if cholesterol } \\
\text { and } 24 \text { hydroxycholesterol } \\
\text { trafficking in the brain } \\
\text { causes AD and CYP46A1 } \\
\text { gene effects on AD }\end{array}$ & $\begin{array}{l}\text { Cholesterol and } 24 \\
\text { hydroxycholesterol, } \\
\text { beta-amyloid plaques, } \\
\text { CYP46A1 genotyping }\end{array}$ & $\begin{array}{l}\text { Beta-amyloid plaques, which is characteristic of } \\
\text { AD, were found with increased CSF } 24 \\
\text { hydroxycholesterol, a mutation in the CYP46A1 } \\
\text { gene causes dysfunctional cholesterol metabolism }\end{array}$ \\
\hline $\begin{array}{l}\text { Caramelli } \\
\text { et al. [47] }\end{array}$ & 1999 & $\begin{array}{l}\text { Case- } \\
\text { control } \\
\text { study }\end{array}$ & $\begin{array}{l}\text { To determine the } \\
\text { relationship between } \\
\text { plasma lipids and AD. }\end{array}$ & $\begin{array}{l}\text { VLDL, HDL-C, LDL-C, } \\
\text { triglycerides, ApoB, } \\
\text { lipoprotein (a) }\end{array}$ & $\begin{array}{l}\text { Significantly higher Apolipoprotein B levels were } \\
\text { found in AD patients, whereas the concentration of } \\
\text { lipoprotein (a) and plasma lipids was not } \\
\text { statistically different. This shows that APOE may } \\
\text { not be the only transporter associated with AD. }\end{array}$ \\
\hline $\begin{array}{l}\text { Raygani } \\
\text { et al. [46] }\end{array}$ & 2006 & $\begin{array}{l}\text { Case- } \\
\text { control } \\
\text { study }\end{array}$ & $\begin{array}{l}\text { To determine the } \\
\text { association between } \\
\text { plasma lipids, ApoE } \\
\text { polymorphism, and with AD }\end{array}$ & $\begin{array}{l}\text { HDL-C, LDL-C, TC, } \\
\text { APOB, APOE4, } \\
\text { APOA1 }\end{array}$ & $\begin{array}{l}\text { Apolipoprotein e4 is associated with AD. Also, } \\
\text { decreased ApoA1, HDL-C, increased ApoB, } \\
\text { increased LDL-C, TC is seen in AD }\end{array}$ \\
\hline $\begin{array}{l}\text { Panza et } \\
\text { al. [10] }\end{array}$ & 2006 & $\begin{array}{l}\text { Literature } \\
\text { review }\end{array}$ & $\begin{array}{l}\text { To determine the } \\
\text { association between TC, } 24 \\
\text { S hydroxycholesterol, LDL- } \\
\text { C, Lp(A), ApoE levels with } \\
\text { AD }\end{array}$ & $\begin{array}{l}\text { TC, } 24 S \text { HC, LDL-C, } \\
\text { Lp(A), APOE }\end{array}$ & $\begin{array}{l}\text { TC, LDL-C, } \operatorname{Lp}(\mathrm{A}) \text { was found to be elevated in } \\
\text { patients with } A D \text {. No consistent association } \\
\text { between } A p o E \text { and } A D \text { have been found in this } \\
\text { study }\end{array}$ \\
\hline $\begin{array}{l}\text { Martins } \\
\text { et al. [5] }\end{array}$ & 2006 & $\begin{array}{l}\text { Literature } \\
\text { review }\end{array}$ & $\begin{array}{l}\text { To understand cholesterol } \\
\text { mechanism, the relation } \\
\text { between } A P O E \text { allele and } \\
A D \text {, determine convergence } \\
\text { risk factors for } A D \text { and } C A D\end{array}$ & APOE $\varepsilon 4$ allele & $\begin{array}{l}\text { APOE } \varepsilon 4 \text { one or more alleles increase the risk of } \\
A D . A \text { decrease in APO A1 is associated with } A D \text {. }\end{array}$ \\
\hline $\begin{array}{l}\text { Kivipelto } \\
\text { et al. [43] }\end{array}$ & 2002 & $\begin{array}{l}\text { Cohort } \\
\text { study }\end{array}$ & $\begin{array}{l}\text { To determine the } \\
\text { association between }\end{array}$ & APOE genotype & APOE $\varepsilon 4$ alleles are associated with AD \\
\hline
\end{tabular}




\section{Cureus}

\section{TABLE 2: Summarizing association between mutations in cholesterol metabolism protein and}

\section{Alzheimer's disease}

LDL-C: low-density lipoprotein cholesterol; HDL-C: high-density lipoprotein cholesterol; TC: total cholesterol; TG: triglycerides; AD: Alzheimer's disease; Apo: apolipoprotein; AB: beta-amyloid; APP: amyloid precursor protein; MCl: mild cognitive impairment; BBB: blood-brain barrier; 24S HC: 24S hydroxycholesterol; 27O-HC: 270 hydroxycholesterol; PSEN: presenilin; ABCA1 and ABCA7: ATP binding cassette transporter 1 and 7; CYP46A1: cytochrome P450 family 46 subfamilies A member 1

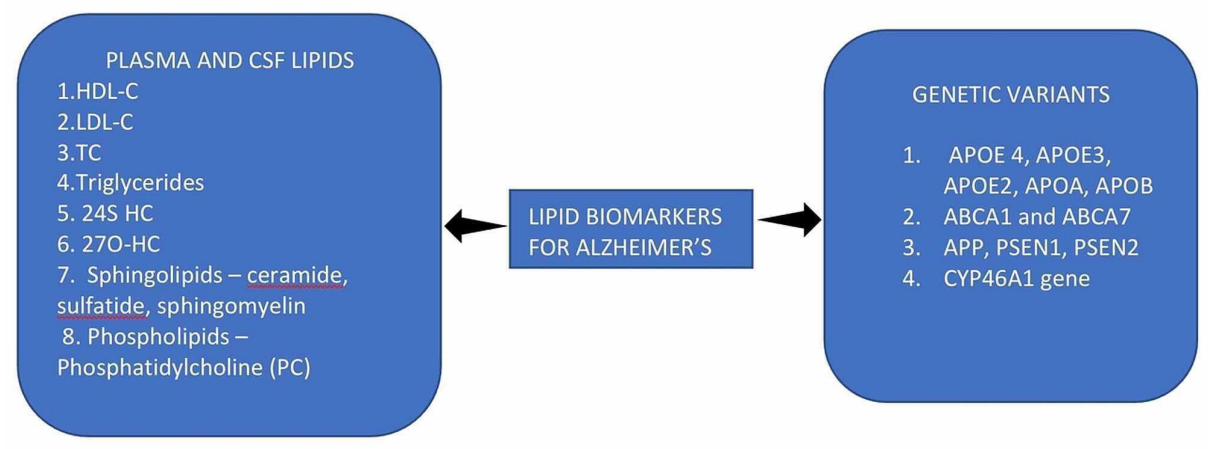

\section{FIGURE 3: Plasma biomarkers of Alzheimer's disease and their genetic} variants

LDL-C: low-density lipoprotein cholesterol; HDL-C: high-density lipoprotein cholesterol; TC: total cholesterol; TG: triglycerides; Apo: apolipoprotein; APP: amyloid precursor protein; 24S HC: 24S hydroxycholesterol; 270-HC: $27 \mathrm{O}$ hydroxycholesterol; PSEN: presenilin; ABCA1 and ABCA7: ATP binding cassette transporter 1 and 7; CYP46A1: cytochrome P450 family 46 subfamilies A member 1

\section{Limitations}

Even though the study clearly shows the relation between $\mathrm{AD}$ and plasma cholesterol, there are many aspects of cholesterol metabolism in the brain that are still not clearly understood. Different studies included in this study have different theories about $\mathrm{AD}$ pathology due to high plasma cholesterol. The exact reasons for polymorphism in many genes and associated $\mathrm{AD}$ also remain unclear. We were also unable to find if these biomarkers are altered by gender and physical activity. Only studies published in English were included; we did not include articles that were in other languages. Case reports, case series, letter to the editor, editorials were not included. Similarly, studies that did not find any association between AD and cholesterol were also excluded.

\section{Conclusions}

We studied many articles on the association between $\mathrm{AD}$ and plasma lipids. Based on those, we found that levels of plasma cholesterol, triglycerides, sphingolipids, phospholipids are altered in $\mathrm{AD}$, and genetic variants of the various cholesterol metabolism-related proteins also lead to AD. The brain is made up of high lipid content, and thus any alteration in the cholesterol metabolism in the brain can cause dysregulation of the brain lipid homeostasis. Cholesterol is associated with the beta-amyloid build-up in the brain, thus increased plasma cholesterol results in increased beta-amyloid plaques, which is pathognomonic of AD. We also found out that ApoE4 and mutations in many other transporters of cholesterol in the brain are linked with increasing the chances of $\mathrm{AD}$. This article thus points out all the lipid-associated risk factors causing AD. This will help us improve our knowledge and scope of the disease. Plasma lipids biomarkers can also be studied by a simple blood test making diagnosis and prediction of AD much easier. However, more advanced studies and research must understand the exact pathology behind this, as brain and peripheral cholesterol are two different entities and separated by a strict BBB.

\section{Additional Information}

\section{Disclosures}

Conflicts of interest: In compliance with the ICMJE uniform disclosure form, all authors declare the following: Payment/services info: All authors have declared that no financial support was received from any organization for the submitted work. Financial relationships: All authors have declared that they have no financial relationships at present or within the previous three years with any organizations that might 
have an interest in the submitted work. Other relationships: All authors have declared that there are no other relationships or activities that could appear to have influenced the submitted work.

\section{References}

1. GBD 2016 Dementia Collaborators: Global, regional, and national burden of Alzheimer's disease and other dementias, 1990-2016: a systematic analysis for the Global Burden of Disease Study 2016. Lancet Neurol. 2019, 18:88-106. 10.1016/S1474-4422(18)30403-4

2. Alzheimer's Association: 2009 Alzheimer's disease facts and figures. Alzheimers Dement. 2009, 5:234-270. 10.1016/j.jalz.2009.03.001

3. Degenerative diseases: Neuropathology. (1998). https://neuropathology-web.org.

4. Reitz C, Mayeux R: Alzheimer disease: epidemiology, diagnostic criteria, risk factors and biomarkers . Biochem Pharmacol. 2014, 88:640-651. 10.1016/j.bcp.2013.12.024

5. Martins IJ, Hone E, Foster JK, et al.: Apolipoprotein E, cholesterol metabolism, diabetes, and the convergence of risk factors for Alzheimer's disease and cardiovascular disease. Mol Psychiatry. 2006, 11:721-736. 10.1038/sj.mp.4001854

6. Jeong W, Lee H, Cho S, Seo J: ApoE4-induced cholesterol dysregulation and its brain cell type-specific implications in the pathogenesis of Alzheimer's disease. Mol Cells. 2019, 42:739-746. 10.14348/molcells.2019.0200

7. Kuo YM, Emmerling MR, Bisgaier CL, Essenburg AD, Lampert HC, Drumm D, Roher AE: Elevated lowdensity lipoprotein in Alzheimer's disease correlates with brain abeta 1-42 levels. Biochem Biophys Res Commun. 1998, 252:711-715. 10.1006/bbrc.1998.9652

8. Wings TS, Cutler DJ, Wingo AP, et al.: Association of early-onset Alzheimer disease with elevated lowdensity lipoprotein cholesterol levels and rare genetic coding variants of APOB. JAMA Neurol. 2019, 76:809817. 10.1001/jamaneurol.2019.0648

9. Proitsi P, Lupton MK, Velayudhan L, et al.: Genetic predisposition to increased blood cholesterol and triglyceride lipid levels and risk of Alzheimer disease: a Mendelian randomization analysis. PLoS Med. 2014, 11:1001713. 10.1371/journal.pmed.1001713

10. Panza F, D'Introno A, Colacicco AM, et al.: Lipid metabolism in cognitive decline and dementia . Brain Res Rev. 2006, 51:275-292. 10.1016/j.brainresrev.2005.11.007

11. Wang H, Wang Y, Liu X, Kuo SH, Liu N, Song QY, Wang MW: Cholesterol, 24-hydroxycholesterol, and 27hydroxycholesterol as surrogate biomarkers in cerebrospinal fluid in mild cognitive impairment and Alzheimer's disease: a meta-analysis. J Alzheimers Dis. 2016, 51:45-55. 10.3233/JAD-150734

12. Chen H, Du Y, Liu S, Ge B, Ji Y, Huang G: Association between serum cholesterol levels and Alzheimer's disease in China: a case-control study. Int J Food Sci Nutr. 2019, 70:405-411. 10.1080/09637486.2018.1508426

13. Mamo JCL, Jian L, James AP, Flicker L, Esselmann H, Wiltfang J: Plasma lipoprotein $\beta$-amyloid in subjects with Alzheimer's disease or mild cognitive impairment. Ann Clin Biochem. 2008, 45:395-403. 10.1258/acb.2008.007214

14. Warren M, Hynan L, Weiner M: Lipids and adipokines as risk factors for Alzheimer's disease . J Alzheimers Dis. 2012, 29:151-157. 10.3233/JAD-2012-111385

15. Sabbagh M, Zahiri R, Ceimo J, Cooper K, Gaul W, Connor D, Sparks DL: Is there a characteristic lipid profile in Alzheimer's disease?. J Alzheimers Dis. 2004, 6:585-589. 10.3233/JAD-2004-6602

16. Yassine HN, Feng Q, Chiang J, Petrosspour LM, Fonteh AN, Chui HC, Harrington MG: ABCA1-mediated cholesterol efflux capacity to cerebrospinal fluid is reduced in patients with mild cognitive impairment and Alzheimer's disease. J Am Heart Assoc. 2016, 5:002886. 10.1161/JAHA.115.002886

17. Kosicek M, Hecimovic S: Phospholipids and Alzheimer's disease: alterations, mechanisms and potential biomarkers. Int J Mol Sci. 2013, 14:1310-1322. 10.3390/ijms14011310

18. Moher D, Liberati A, Tetzlaff J, Altman DG, PRISMA Group: Preferred reporting items for systematic reviews and meta-analyses: the PRISMA statement. PLoS Med. 2009, 6:1000097. 10.1371/journal.pmed.1000097

19. Björkhem I, Meaney S: Brain cholesterol: long secret life behind a barrier . Arterioscler Thromb Vasc Biol. 2004, 24:806-815. 10.1161/01.ATV.0000120374.59826.1b

20. Wong MW, Braidy N, PoljakA, Pickford R, Thambisetty M, Sachdev PS: Dysregulation of lipids in Alzheimer's disease and their role as potential biomarkers. Alzheimers Dement. 2017, 13:810-827. 10.1016/j.jalz.2017.01.008

21. Martín MG, Pfrieger F, Dotti CG: Cholesterol in brain disease: sometimes determinant and frequently implicated. EMBO Rep. 2014, 15:1036-1052. 10.15252/embr.201439225

22. Chew H, Solomon VA, Fonteh AN: Involvement of lipids in Alzheimer's disease pathology and potential therapies. Front Physiol. 2020, 11:598. 10.3389/fphys.2020.00598

23. Pappolla MA, Bryant-Thomas TK, Herbert D, et al.: Mild hypercholesterolemia is an early risk factor for the development of Alzheimer amyloid pathology. Neurology. 2003, 61:199-205. 10.1212/01.WNL.0000070182.02537.84

24. Iqbal $\mathrm{G}$, Braidy $\mathrm{N}$, Ahmed $\mathrm{T}$ : Blood-based biomarkers for predictive diagnosis of cognitive impairment in a Pakistani population. Front Aging Neurosci. 2020, 12:223. 10.3389/fnagi.2020.00223

25. Proitsi P, Kim M, Whiley L, et al.: Association of blood lipids with Alzheimer's disease: a comprehensive lipidomics analysis. Alzheimers Dement. 2017, 13:140-151. 10.1016/j.jalz.2016.08.003

26. Wolf H, Hensel A, Arendt T, Kivipelto M, Winblad B, Gertz HJ: Serum lipids and hippocampal volume: the link to Alzheimer's disease?. Ann Neurol. 2004, 56:745-748. 10.1002/ana.20289

27. Formiga F, Ferrer A, Chivite D, Pinto X, Badia T, Padrós G, Pujol R: Serum high-density lipoprotein cholesterol levels correlate well with functional but not with cognitive status in 85-year-old subjects. J Nutr Health Aging. 2012, 16:449-453. 10.1007/s12603-012-0018-z

28. Jensen CS, Musaeus CS, Frikke-Schmidt R, et al.: Physical exercise may increase plasma concentration of high-density lipoprotein-cholesterol in patients with Alzheimer's disease. Front Neurosci. 2020, 14:532. 
10.3389/fnins.2020.00532

29. Helzner EP, Luchsinger JA, Scarmeas N, Cosentino S, Brickman AM, Glymour MM, Stern Y: Contribution of vascular risk factors to the progression in Alzheimer disease. Arch Neurol. 2009, 66:343-348.

10.1001/archneur.66.3.343

30. Solfrizzi V, D'Introno A, Colacicco AM, et al.: Circulating biomarkers of cognitive decline and dementia . Clin Chim Acta. 2006, 364:91-112. 10.1016/j.cca.2005.06.015

31. Hall JR, Wiechmann AR, Johnson LA, et al.: Total cholesterol and neuropsychiatric symptoms in Alzheimer's disease: the impact of total cholesterol level and gender. Dement Geriatr Cogn Disord. 2014, 38:300-309. $10.1159 / 000361043$

32. He Q, Li Q, Zhao J, Wu T, Ji L, Huang G, Ma F: Relationship between plasma lipids and mild cognitive impairment in the elderly Chinese: a case-control study. Lipids Health Dis. 2016, 15:146. 10.1186/s12944016-0320-6

33. Solomon A, Kåreholt I, Ngandu T, et al.: Serum cholesterol changes after midlife and late-life cognition, Twenty-one-year follow-up study. Neurology. 2007, 68:751-756. 10.1212/01.wnl.0000256368.57375.b7

34. Anstey KJ, Ashby-Mitchell K, Peters R: Updating the evidence on the association between serum cholesterol and risk of late-life dementia: review and meta-analysis. J Alzheimers Dis. 2017, 56:215-228. 10.3233/JAD160826

35. Sáiz-Vazquez O, Puente-Martínez A, Ubillos-Landa S, Pacheco-Bonrostro J, Santabárbara J: Cholesterol and Alzheimer's disease risk: a meta-meta-analysis. Brain Sci. 2020, 10:386. 10.3390/brainsci10060386

36. Moroney JT, Tang M, Berglund L, et al.: Low-density lipoprotein cholesterol and the risk of dementia with stroke. JAMA. 1999, 282:254-260. 10.1001/jama.282.3.254

37. Zhou Z, Liang Y, Zhang X, et al.: Low-density lipoprotein cholesterol and Alzheimer's disease: a systematic review and meta-analysis. Front Aging Neurosci. 2020, 12:5. 10.3389/fnagi.2020.00005

38. Wu Y, Wang Z, Jia X, et al.: Prediction of Alzheimer's disease with serum lipid levels in Asian individuals: a meta-analysis. Biomarkers. 2019, 24:341-351. 10.1080/1354750X.2019.1571633

39. Liu Y, Zhong X, Shen J, et al.: Elevated serum TC and LDL-C levels in Alzheimer's disease and mild cognitive impairment: a meta-analysis study. Brain Res. 2020, 1727:146554. 10.1016/j.brainres.2019.146554

40. Bernath M, Bhattacharyya S, Nho K, et al.: Serum triglycerides in Alzheimer disease: relation to neuroimaging and CSF biomarkers. Neurology. 2020, 94:2088-2098. 10.1212/WNL.0000000000009436

41. Popp J, Meichsner S, Kölsch H, et al.: Cerebral and extracerebral cholesterol metabolism and CSF markers of Alzheimer's disease. Biochem Pharmacol. 2013, 86:37-42. 10.1016/j.bcp.2012.12.007

42. Costa AC, Joaquim HPG, Forlenza O, Talib LL, Gattaz WF: Plasma lipids metabolism in mild cognitive impairment and Alzheimer's disease. World J Biol Psychiatry. 2019, 20:190-196. 10.1080/15622975.2017.1369566

43. Kivipelto M, Helkala EL, Laakso MP, et al.: Apolipoprotein E epsilon4 allele, elevated midlife total cholesterol level, and high midlife systolic blood pressure are independent risk factors for late-life Alzheimer disease. Ann Intern Med. 2002, 137:149-155. 10.7326/0003-4819-137-3-200208060-00006

44. Toro P, Degen C, Pierer M, Gustafson D, Schröder J, Schönknecht P: Cholesterol in mild cognitive impairment and Alzheimer's disease in a birth cohort over 14 years. Eur Arch Psychiatry Clin Neurosci. 2014, 264:485-492. 10.1007/s12603-012-0018-z

45. Agarwal R, Tripathi CB: Association of apolipoprotein E genetic variation in Alzheimer's disease in Indian population: a meta-analysis. Am J Alzheimers Dis Other Demen. 2014, 29:575-582. 10.1177/1533317514531443

46. Raygani AV, Rahimi Z, Kharazi H, Tavilani H, Pourmotabbed T: Association between apolipoprotein E polymorphism and serum lipid and apolipoprotein levels with Alzheimer's disease. Neurosci Lett. 2006, 408:68-72. 10.1016/j.neulet.2006.08.048

47. Caramelli P, Nitrini R, Maranhão R, Lourenço AC, Damasceno MC, Vinagre C, Caramelli B: Increased apolipoprotein B serum concentration in Alzheimer's disease. Acta Neurol Scand. 1999, 100:61-63. 10.1111/j.1600-0404.1999.tb00724.x

48. Li H, Zhou J, Yue Z, et al.: A complex association between ABCA7 genotypes and blood lipid levels in Southern Chinese Han patients of sporadic Alzheimer's disease. J Neurol Sci. 2017, 382:13-17. 10.1016/j.jns.2017.09.016

49. Lukiw WJ: Cholesterol and 24S-hydroxycholesterol trafficking in Alzheimer's disease. Expert Rev Neurother. 2014, 6:683-693. 10.1586/14737175.6.5.683 